\begin{tabular}{l}
\hline Computer Assisted \\
Language Instruction \\
Consortium \\
\hline
\end{tabular}

Article

\title{
Researching Identity and L2 Pragmatics in Digital Stories: A Relational Account
}

\author{
Maria Dolores García-Pastor
}

\begin{abstract}
This study explores college EFL learners' construction of identity through the analysis of their pragmatic choices in digital stories, in which they narrated their relationship with another person they had helped in the past. More specifically, such choices were examined following Relational Dialectics Theory in learners' enactments of "connection" with and "autonomy" from this person. A specific view of identity in language education, the notion of "relational work" in (im)politeness research, and a social semiotic framework were also employed in data analysis. Learners' pragmatic choices ranged from the selection of the topic of their narratives according to types of social bonds, to the use of specific semiotic resources to build identities in conflict episodes of their stories (i.e., positive identities for themselves and positive and negative identities for their relational partners). The construction of these identities paralleled relational parties' convergent and divergent moves towards connection and autonomy, revealing their relational work. Learners used different semiotic resources in resolution episodes, which enabled them to craft positive identities for themselves as experts, teachers, and learners as well as position their relational partner as a competent agent and shape the connection-autonomy dialectic as "superiority-equality".

Keywords: identity; L2 PRagmatics; Relational Dialectics Theory; RELATIONAL WORK; DIGITAL STORIES.
\end{abstract}

\footnotetext{
$\overline{\text { Affiliation }}$

University of Valencia, Spain.

email: maria.d.garcia@uv.es

CALICO JOURNAL VOL $37.12020 \quad 46-65$

(C) 2020, EQUINOX PUBLISHING
}

https://doi.org/10.1558/cj.38777

e日uinox

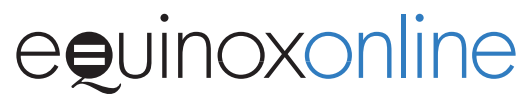




\section{Introduction}

Interest in identity has recently been growing in language education as a consequence of social orientations of language learning (Norton \& De Costa, 2018; Norton \& Toohey, 2011). In interlanguage pragmatics (ILP), identity has also gained momentum through studies that explore the learner's convergence with, or divergence from, target language norms and their effect on L2 pragmatic choices (Gómez-Laich, 2016). This has also been observed in investigations that focus on the learner's communicative practices in digital environments (Thorne, Sauro, \& Smith, 2015). Yet, the relationship between pragmatic competence and L2 identity in digital spaces is still an "underresearched area" (Thorne et al., 2015, p. 220) with the exception of Kim and Brown's (2014) work on the affordances of digital mediation for both L2 pragmatic use and development, and the construction, negotiation, and transformation of L2 learners' identities.

This study attempts to address the relationship between technology and identity building by exploring L1 Spanish college learners' pragmatic choices for identity construction in digital stories within an English as a foreign language (EFL) course. To this end, this research draws on Norton's $(1995,2013)$ view of identity in language education, Baxter and Montgomery's (1996) theory of relationships, Locher and Watts' $(2005,2008)$ notion of "relational work," and Kress and van Leeuwen's (2006) social semiotic framework. In order to examine the interrelation between L2 pragmatics and identity in such stories, the study takes into account students' knowledge and ability to use semiotic resources for conveying illocutionary and interpersonal meanings in L2 English (i.e., pragmalinguistics) and their knowledge and ability to utilize the social conventions underlying target language use (i.e., sociopragmatics) (Leech, 1983).

An interactional view of pragmatics implies considering (im)politeness a crucial aspect of a learner's pragmatic competence (Alcón Soler \& MartínezFlor, 2008; García-Pastor, 2012; Kasper, 1990). (Im)politeness in this study is conceptualized as "relational work" (Locher \& Watts, 2005, 2008), which refers to the situated discursive enactment of social bonds. As such, it is unavoidably interlinked with speakers' identities, since it is in, and through, our relations with others that we acquire and develop a sense of who we are (Baxter \& Montgomery, 1996; Locher, 2008). Therefore, this study examines how learners craft their identities in their instantiations of their relationship with another person through their digital stories by scrutinizing their pragmatic choices in their enactments of connection with, and autonomy from, this relational party. In so doing, it is hoped that the study will enhance our understanding of the relationship between learners' target language use and identities in digital spaces.

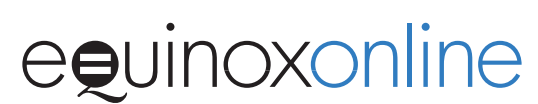




\section{L2 Pragmatics and Identity: A Focus on Digital Spaces}

Identity in ILP has been indirectly addressed in studies that deal with politeness through learners' use of conversational routines, semantic formulae, and other linguistic devices (e.g., downgraders) (Beebe \& Takahashi, 1989; BlumKulka, 1990; Félix-Brasdefer, 2004; Wildner-Bassett, 1994). These investigations implicitly equate identity with the learner's self-presentation and the image native speakers may attribute to him/her. This happens in cases of "sociopragmatic failure", namely, situations in which s/he fails to use the L2 appropriately due to cross-cultural differences in the assessment of social factors affecting communication (Thomas, 1983). Previous studies hint at the idea that identity is non-unitary through the potential clash between a learner's self-image and others' perception of him/her. However, they do not unravel this construct, and suggest that the learner should comply with the politeness norms of the target community to be considered a competent language user and not appear rude. Research looking into rudeness as a component of pragmatic competence follows a similar line of argument, in spite of highlighting the learner's agency in responding to this phenomenon (Beebe \& Waring, 2005).

ILP studies dealing with identity problematize it by acknowledging the possibility that learners diverge from L2 standards of linguistic action if they do not match who they are and their desired identity in a given situation (see Gómez-Laich, 2016). As an example, in L2 Japanese, Siegal (1996) documents a young female learner's discomfort with the use of honorifics in a conversation with her male professor. This learner perceived these forms as mirroring a too humble female speech style that clashed with her L1 English gender identity. Similarly, Iwasaki (2011) shows four American male Japanese learners' resistance to the polite desu/masu forms in certain situations due to the association of these forms with social distance, and therefore with identities that were incompatible with the construction of a friendly American identity. Ishihara and Tarone (2009) report analogous findings. The learners in their study resisted the use of keigo (honorifics) and gendered language, thus refraining from signalling social hierarchy and unequal distribution of power in relationships.

In L2 English, Ishihara (2009) presents an L1 Japanese volleyball instructor's deliberate flout of the informal and egalitarian L2 norms of the target athletic community through her resistance to receive direct requests from her young American student players. Also, in L2 English, Kim (2014) demonstrates that age and length of stay influenced Korean ESL learners' convergence with, and divergence from, target language norms in responding to compliments, making requests, and using titles. In Kim's study, younger learners were more open to follow L2 norms, and length of stay was found to interact with age in

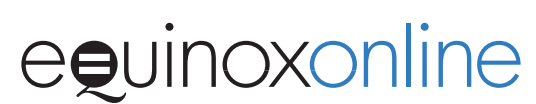


learners' decisions to maintain their L1 identity or align with L2 norms. Even when learners hold a positive view of English and manifest a desire to learn the foreign language, some are reluctant to adopt norms for fear of losing their own identities, as found in LoCastro's (2001) study of college Japanese EFL learners' subjectivities, attitudes, and motivation towards accommodating to target language norms.

Other studies show how certain learners perform identity by adopting other L2 modes of pragmatic expression as opposed to relying on L1 norms (Davis, 2007; Hassall, 2013). For example, Davis (2007) illustrates how high-proficiency Korean ESL learners resisted the use of Australian English pragmatic routines in favour of North American English ones because these routines in Australian English were inconsistent with their sense of self. Similarly, Australian learners of L2 Indonesian in Hassall's (2013) research did not feel that they needed to employ address terms appropriately in this language given the identity of "outsiders" they had been attributed in the target culture. Conforming to an "outsider" identity constrained their opportunities for target-like use and convergence with L2 norms.

Research on identity and its relation to L2 pragmatics in digital spaces has been scarce (Black, 2009; Chen, 2013; Fong, Lin, \& Engle, 2016; Kim \& Brown, 2014; Klimanova \& Dembovskaya, 2013; Thorne \& Black, 2011; Thorne et al., 2015; Yi, 2007). These investigations focus on learners' use of linguistic elements (e.g., terms of address) and other semiotic resources to account for their pragmatic competence, their multilingual literacy practices and development, their establishment of social bonds, and their creation of multiple identities in such contexts (Thorne et al., 2015). Kim and Brown (2014) explore four L1 English learners' use of Korean honorifics and kinship terms in naturalistic computer-mediated interactions with native speakers. Within their limited competence, these learners employed these elements in a manner that helped them craft their identities as legitimate Korean language users. Black (2009) shows how three adolescent English language learners writing in an online fanfiction community built identities as accomplished users of multiple languages by foregrounding different aspects of their identities that enabled them to enact cosmopolitan identities, make transnational social connections, and experiment with new genres and formats for composing. Likewise, Klimanova and Dembovskaya (2013) investigate how American learners of Russian discursively built and negotiated their identities as L2 learners and legitimate speakers of Russian, as they engaged with native speakers in telecollaborative tasks within a popular Russian social networking site. These learners constructed their identities through solicited or volunteered error correction, code-switching, form-focused and meaning-focused activities, punctuation conventions, and the use of multimodal elements.

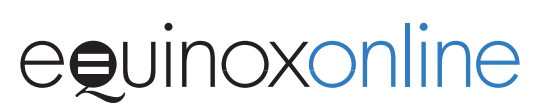


Thorne and Black (2011) show how college American learners of French and high school learners of Spanish built meaningful relationships with French and Spanish learners of English respectively, gained a sense of self-efficacy, and articulated and performed relevant L2 selves through fluid shifts of language choice, stance and style in instant messaging, blogging, and other online activities. These authors further illustrate these findings through the literacy practices and development of an Asian heritage English language learner in a fanfiction site. Similarly, Yi (2007) reports on a 1.5 generation student's out-ofschool online and offline composing practices in L1 Korean and L2 English to illustrate her biliterate development and her construction of a strong identity as a writer and multilingual user. Chen (2013) examines two multilingual writers' longitudinal choices of L1 Mandarin Chinese and L2 English along with their status-updates and information-sharing in Facebook to demonstrate how their literacy practices and development enabled them to craft competent identities as L1 and L2 users, and establish and maintain social bonds across local and global communities. Finally, ESOL learners in Fong et al.'s (2016) research also strengthened their relationships and jointly created positive identities as competent English learners by mutually taking up their positioning proposals within joint actions projected by one participant and taken up by others in an online chat medium.

\section{Identity, Relational Dialectics, and Relational Work}

Along the lines of the investigations just discussed, identity in this study is conceptualized as a fluid, diverse, often contradictory, with multiple notions which learners jointly negotiate and socially construct in their interactions with others (Norton, 1995, 2013). Thus, identity is always in the making and cannot be understood without considering the manner and degree in which learners participate in social life. Such participation is highly mediated by technology at present, and involves a struggle from the learner to increase their L2 linguistic and cultural capital to achieve competent identities in the present or in the future (imagined identities), as well as to resist silencing identities they may be ascribed by framing their relations with their interlocutors in specific ways (Darvin \& Norton, 2015; Norton, 1995, 2013; Norton \& Toohey, 2011).

Accordingly, identity is a relational construct that can only be defined in and through dialogue, as established in Relational Dialectics Theory (Baxter \& Montgomery, 1996). "Dialogue" refers to the recognition of a voice of difference that can be a literal spoken voice of another embodied person, or a different ideology or worldview. Therefore, dialogue can only be enacted in fusion yet simultaneous differentiation from an "other". "I" emerges in dialogue through the struggle of the different, often competing, discourses of speaker and listener

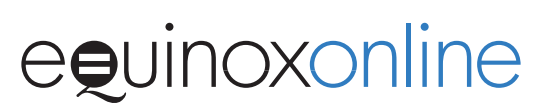


who jointly craft it in social interaction. Such competing discourses define relationships and shape identities in terms of a series of oppositions which constitute "the central organising feature of social life" (Baxter, 1993, p. 140). These oppositions are interdependent with one another and are always in ongoing dynamic interaction or "dialectical tension".

Internal oppositions emerge within the social dyad, whereas external oppositions ensue in the dialectical tension between the dyad and the macro social order. Along the internal-external continuum, Baxter and Montgomery (1996) identify the dialectics of integration-separation, expression-privacy, and stability-change. Integration-separation refers to the simultaneous need for fusion with, and differentiation from, the "other" that relational parties experience at different points in their relationship. In its internal manifestation, it consists of the tension between connection and autonomy of the two parties in a relationship. In its external manifestation, it captures the inclusion-seclusion contradiction that illustrates the relational pair's involvement with, and isolation from, other relational dyads. The dialectic of expression-privacy focuses on "what is expressed versus what is not expressed" (Baxter, 1993, p. 143). Therefore, internally, it refers to the openness-closedness tension relational parties maintain with one another through self-disclosure or concealment of information. Externally, it refers to the extent to which they reveal or conceal information to others. Finally, stability-change illustrates the tension between the given and the new, and therefore the dyad's need for routine or renewal. At an internal level, it involves predictability and uncertainty in the perceptions and behaviours of relational parties when they interact with each other. At an external level, it refers to their conventionality and uniqueness in their reproduction of social norms regarding ways of relating or their deviation from these respectively.

As indicated above, politeness and impoliteness consist of a continuum of verbal and non-verbal behaviours which encompass the interpersonal side of communication. Such view has been advocated by discursive approaches to (im)politeness, which have brought about a paradigm shift in its study that has crucially affected L2 pragmatics research (Iwasaki, 2011). A relevant perspective in this regard is Locher and Watts' $(2005,2008)$ theory of "relational work", i.e., the work individuals invest in discursively negotiating their relations with others. Individuals' negotiation of social bonds entails making judgments about what is polite, impolite, or simply appropriate or inappropriate against a backdrop of norms that guide social interaction in a particular communicative situation. Such norms emerge and are constantly negotiated by individuals within specific communities of practice (Locher \& Watts, 2008). They consist of structures of expectations or organized sets of knowledge (Tannen, 1993), which explain a person's predisposition to act in a determinate manner and perceive their own and others' social conduct as, for example, polite or rude (Locher \& Watts, 2005).

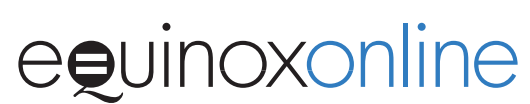


Relational work thus needs to be situated in reference to social norms, which individuals may decide to follow or breach by performing certain communicative actions and making judgements regarding social conduct in the creation, maintenance, transformation, and termination of social bonds. Relational work involves a discursive struggle between interactants over relational meaning. This entails the negotiation of identities, which individuals construct through the social positioning of self and other (Locher, 2008). Therefore, identity emerges in social interaction as the "product" of semiotic processes of meaning making that take place in relational work, in such a way that it is always "in flux" (Locher, 2008, p. 511), and acquires social meaning in relation to other identity positions and other social actors in interaction. This accounts for its nature as a site of struggle, as established also by Norton $(1995,2013)$, and Baxter and Montgomery (1996) through the contradictory and multivocal nature of relationships. In any case, the semiotic processes of meaning making that ensue in individuals' discursive negotiation of their identities and their social bonds are necessarily based on specific resources they choose to convey illocutionary and interpersonal meanings.

\section{Methods}

Considering the above, this study aims at answering the following research question: what are the pragmatic choices learners make in EFL to build their identities in their enactments of connection-autonomy in digital stories?

\subsection{Participants}

The participants were 54 L1 Spanish college EFL learners, 45 females and 9 males, who were enrolled in an English as a foreign language (EFL) course at a Spanish university during the study. They ranged in age from 21-30 with an average age of 23. All had a B2 level of English as measured by the Oxford Online Placement Test.

The teacher is also the researcher with 23 years of experience in the teaching of EFL and 13 years in second language teacher education.

\subsection{Corpus and Data Collection Procedures}

The data set entails 54 digital stories of 3-5 minutes duration, in which learners narrated in English their relationship with another person of their choice whom they had helped in the past. Specifically, they were asked to describe and reflect upon their experience in helping this individual in terms of the effects of their actions in this person and themselves. The main aim of this digital task was to raise learners' awareness of how relating to others contributes to defining who we are.

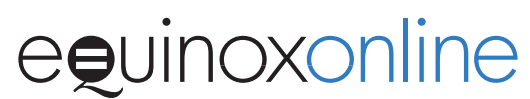


Concerning format, learners were required to incorporate images and/or video and music in their digital products using any photo or video editing program they felt comfortable with. They had freedom to use visual text, their own voice, or both in these stories. The production of the stories was preceded by a small group discussion activity in which learners worked through a series of questions about the story of a senior teacher who helped an underachieving student in an attempt to make a difference in his life (Renandya, in press). This activity took place in the first of the eight class sessions that were devoted to the digital storytelling task. Learners' discussions (five in total) were meant to help them think about the content and form of their stories. These sessions were recorded with their permission to be used as secondary data by the author to better understand learners' digital texts.

Training on the digital story production process was not necessary since learners were familiar with the technological tools and the creation of digital storytelling. Class time was devoted instead to the crafting, revision, and narration of the story through a series of graphic organizers. Example 1 illustrates the statements of Participant 44 in a graphic organizer on the conclusion stage of personal digital stories after reflecting on how helping a school friend changed him.

\section{Example 1}

Participant 44

\section{Conclusion (paragraph content)}

It is true that my former self still follows me, but it has now become a part of who I am. I now enjoy working hard and I try my best to perform to my full extent. I don't need appraisal, but I must say, I kind of miss it from time to time.

\section{Your story}

\section{Does your conclusion relate to the paragraphs in your text? How?}

Finally, I end up going back to the beginning by relation to my former self. I also talk about my relationship with the pressure and the appraisal mentioned in the beginning of the text.

Learners also agreed to record their own composing process, which was also used as secondary data to interpret more accurately their digital products.

\subsection{Analysis}

The analysis of learners' digital stories first consisted of identifying instances of connection-autonomy, for example, by paying attention to their use of terms conveying closeness to, and distance from, the other relational pair. Then how learners crafted their own and the other party's identities in these specific relational enactments was examined by considering their pragmatic choices

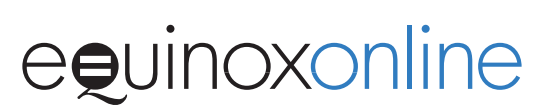


in terms of (a) the topic they selected for their digital stories according to types of social bonds, (b) the kind of communicative acts they performed, and (c) their use of resources such as evaluative language, and quotation in L2 English, as these elements have typically indexed identities in discourse (Wortham, 2006). In the analysis of learners' identity construction in their instantiations of connection-autonomy, learners' acceptance or rejection of identities that were ascribed to them and their relational partner by other social actors (parents, teachers, family relatives, etc.), and the competent, imagined, and silencing identity categories that Norton $(1995,2013)$ distinguishes in her theory were also taken into account.

Since identity work is part of relational work (Locher, 2008), the latter was also examined through learners' performance of communicative acts and their use of the aforementioned semiotic resources for meaning making. In so doing, following Locher and Watts $(2005,2008)$, learners' evaluation of their own and the other's behaviour, and the discursive struggle emerging in relational work was considered.

Learners' use of images was also addressed by drawing on Kress and van Leeuwen's (2006) framework. More specifically, their distinction between narrative and conceptual images, namely, images that present "unfolding actions, events, processes of change, and transitory spatial arrangements" (Kress \& van Leeuwen, 2006, p. 59) was followed as well as those images that represent objects, events, and participants in terms of their stable and timeless essence. Within narrative images, explicit and implicit images were distinguished, i.e., literal images and images that add another layer of meaning to an image's literal meaning (Lambert, 2010).

\section{Results and Discussion}

\subsection{Topic Selection, Identity, and Connection-Autonomy}

Learners' pragmatic choices to build their identities in their enactments of connection-autonomy in their digital stories included general choices such as topic selection in light of different types of social bonds, and specific choices related to the performance of communicative acts and the use of semiotic resources. Learners' conceptualization of the task influenced these choices, generating differences across their stories in their focus on different types of relationships and their preferences for conveying illocutionary and interpersonal meanings.

Many learners perceived the short story of the teacher who assisted an underachieving student, in the small group discussion activity preceding the task, as the kind of story they had to narrate, in spite of their freedom to concentrate on their relation with any person they had helped. This activity was intended to give learners ideas for the content and form of their texts and

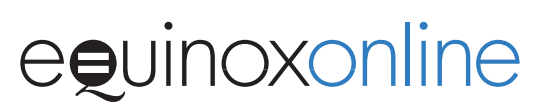


did not mean to limit their choices to the type of social bond and narrative it displayed. However, most learners reproduced this story and focused on their relationship with an underachieving child ( 27 out of 54 texts). The selection of this type of bond as the topic of their stories enabled them to build competent and imagined identities for themselves, and competent identities for the child, whilst simultaneously enacting connection with and autonomy from the latter.

Other learners viewed the story in the small group discussion activity as an example they could follow among other options, and created their stories around their relation with a family relative (a grandmother, a grandfather, a cousin, a nephew, or a sibling) (16 texts). This topic enabled them to easily connect their learning experiences in their academic and family contexts, as shown elsewhere (García-Pastor, 2018a, 2018b, in press). According to Norton and Toohey (2011), establishing links between in- and out-of-school contexts enhances learners' identity options, increasing the likelihood for powerful identity formation. These learners crafted genuine and competent selves through such links, whilst constructing positive identities for their relational partner, after the partner experienced a process of identity transformation. In this process, both parties aligned differently with connection and autonomy in their relationship.

Similarly, some students decided to write about their bond with a school friend (nine texts). The implications of this topic for identity construction and connection-autonomy were the same as in family relative stories, i.e., learners constructed positive identities for themselves and their school friend after this party underwent an identity change, and both relational partners showed divergent moves towards connection and autonomy during the process. Finally, one student dealt with her relationship with many individuals (parents, friends, and teachers), and another student told the story of her relationship with her boyfriend. In both cases, learners built positive identities for themselves and their relational partners.

In sum, learners' selection of the topic for their digital stories, in terms of types of social bonds, affected identity construction and their enactments of connection-autonomy in their texts. In addition, the stages of the genre, especially the conflict and the resolution (García-Pastor, 2017; Robin, 2016), also influenced identity and relational work.

\subsection{Pragmatic Choices, Identity, and Connection-Autonomy in Conflict Episodes}

Conflict episodes in learners' digital stories described a turning point in their relationship with the other main story character. Learners' pragmatic choices for identity construction and relational work in terms of connection-autonomy in these episodes were slightly different in stories about an underachieving child, and stories about a school friend and a family relative. In underachieving

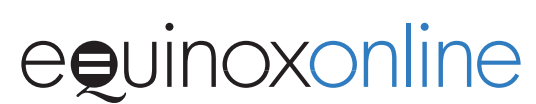


child stories, these choices included supportive acts to both ego and alter, and positive evaluative adjectives within the latter. In school friend and family relative narratives, learners' pragmatic choices included the use of (a) selforiented supportive acts, (b) negative qualifying adjectives in other-directed unsupportive acts, and (c) indirect and direct quotations. In all three types of stories, these resources were accompanied mostly by explicit narrative images. Table 1 summarizes these findings.

Table 1

Pragmatic Choices in Conflict Episodes

\begin{tabular}{|c|c|c|}
\hline $\begin{array}{l}\text { Underachieving child } \\
\text { stories }\end{array}$ & Family relative stories & School friend stories \\
\hline $\begin{array}{l}\text { Communicative acts: } \\
\text { Supportive (self- and } \\
\text { other-oriented) }\end{array}$ & $\begin{array}{l}\text { Communicative acts: } \\
-\quad \text { Supportive } \\
\quad \text { (self-oriented) } \\
-\quad \text { Unsupportive } \\
\text { (other-oriented) }\end{array}$ & $\begin{array}{l}\text { Communicative acts: } \\
\text { Supportive (self-oriented) } \\
\text { Unsupportive } \\
\text { (other-oriented) }\end{array}$ \\
\hline \multirow[t]{2}{*}{$\begin{array}{l}\text { Upgraders and downgraders: } \\
-\quad \text { Positive qualifying } \\
\text { adjectives } \\
\text { (other-oriented) }\end{array}$} & $\begin{array}{l}\text { Upgraders and } \\
\text { downgraders: } \\
\text { - } \quad \text { Negative qualifying } \\
\text { adjectives } \\
\text { (other-oriented) }\end{array}$ & $\begin{array}{l}\text { Upgraders and downgraders: } \\
-\quad \text { Negative qualifying } \\
\text { adjectives } \\
\text { (other-oriented) }\end{array}$ \\
\hline & $\begin{array}{l}\text { Quotations: } \\
-\quad \text { Direct and indirect }\end{array}$ & $\begin{array}{l}\text { Quotations: } \\
-\quad \text { Direct and indirect }\end{array}$ \\
\hline Explicit narrative images & Explicit narrative images & Explicit narrative images \\
\hline
\end{tabular}

Learners' use of these specific semiotic resources within conflict episodes of underachieving child stories helped them craft a positive identity for themselves and the child, which clashed with the silencing identities that parents, teachers, and classmates ascribed him/her. Learners thus empowered the child in their stories and rendered themselves as sensitive individuals capable of resisting certain social identities. These resources also served to intensify the learners' and the child's fluctuations between connection and autonomy, their positive evaluation of their own and the child's behaviour, and their negative evaluation of others' behaviour. Figure 1 illustrates these findings.

This example is part of the story of Participant 38, which is based on her relationship with a child with special educational needs. It narrates a conflict episode in which the learner momentarily describes the child negatively and enacts autonomy by acknowledging that "it was difficult to work with him" (vignette 2). However, she initiates connection with the child by means of a positive qualifying adjective ("normal") (vignette 4) within an other-oriented

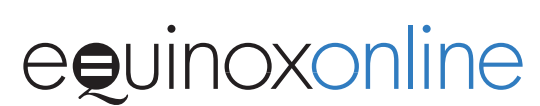




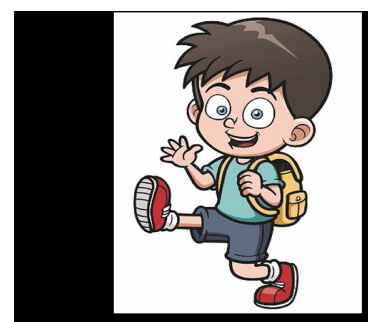

I remember when I arrived to that school and the teacher told me about this situation. The child was 9 years old

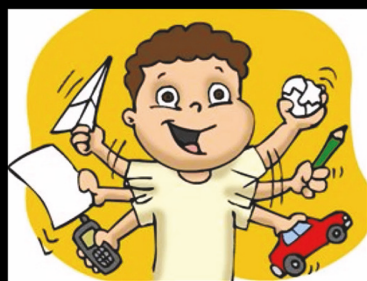

Moreover, he was standing up all the time, and in fact, he only wanted to play, and

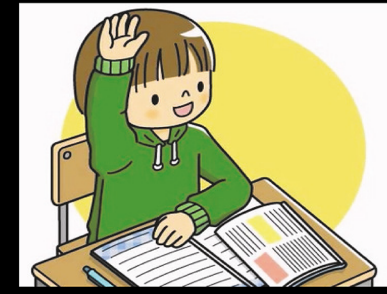

that he always were raising his hand, and I could see how the teacher didn't tell him anything, because he thought

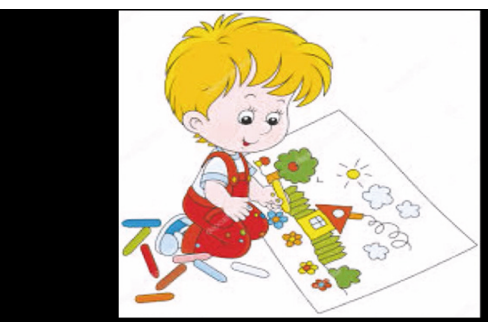

but he actually was three. It was difficult to work with him.

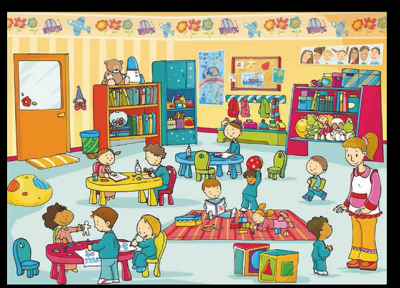

if we think about it, it was normal. I also remember

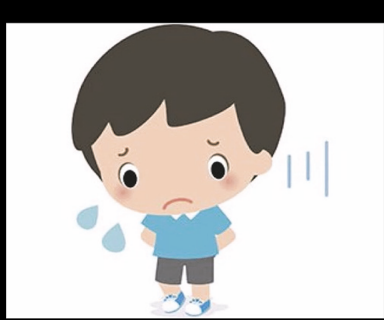

that this child was going to say things with no sense

Figure 1. Extract from Participant 38's story.

supportive act as justification for his seemingly disruptive behaviour ("he only wanted to play"). The learner thus evaluates the kid's conduct positively, empowers him, downplays the silencing identity he was ascribed by his teacher who did not let him talk (vignettes 5 and 6), and implicitly claims for herself an identity of sensitive individual, all of which increases her connection with him. The explicit narrative images the learner selects support her verbal description of the child as a three year-old (vignette 2 ), an active child (vignette 3 ) who only wanted to play (vignette 4), and a kid willing to participate in class (vignette 5), in spite of being denied the opportunity to speak (vignette 6). 
Learners' pragmatic choices in conflict episodes of family and school stories, as illustrated in Table 1 above, enabled them to build an identity of inauthentic individual for their relational partner and an identity of sensitive persona for themselves. This identity clash paralleled a relational clash that was observed in the learner's move towards connectedness and their partner's pull towards autonomy. These divergent alignments with connectedness-separateness also involved learners' evaluation of their own and the other person's conduct, all of which revealed both parties' relational work and the discursive struggle emerging thereof.

Learners' use of quotations to build such identities, and to negotiate their relations as described, indicate their awareness of the oral nature of digital stories and their affordances to bridge oral and written genres, as established in digital storytelling studies (e.g., Gregori-Signes, 2008; Oskoz \& Elola, 2016). Figure 2 exemplifies these findings.

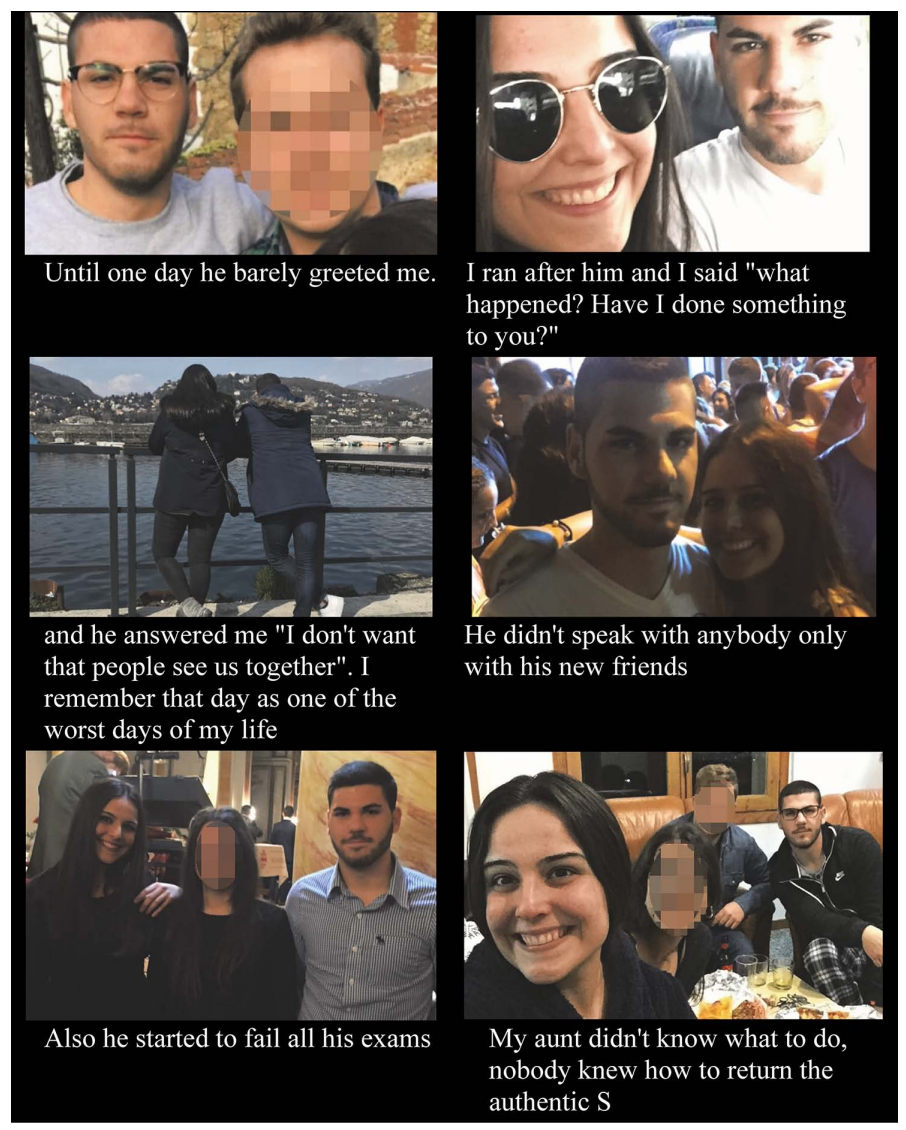

Figure 2. Example from Participant 2's story.

\section{eevinoxonline}


This example belongs to the digital text of Participant 2, who tells the story of her relationship with her cousin. It illustrates a conflict episode, in which the learner builds a positive identity for herself and a negative identity for her cousin in the relational clash that emerged between both. This clash is based on the learner's move towards connection and her cousin's move towards autonomy. The learner resorts to other-oriented unsupportive acts and direct quotation to render her cousin's autonomy moves negatively, as observed in his refusal to greet her (vignette 1), his desire to avoid physical contact with her (vignette 3), and his interruption of verbal contact with his old friends (vignette 4). By contrast, she depicts her connection moves positively through direct quotation and a self-oriented supportive act sequence, through which she intends to repair perceived relational damage (vignette 2). In her negotiation of the relationship, she implicitly crafts herself positively as an "old friend" of his cousin (vignette 4) and renders him negatively as a bad student (vignette 5) and an unauthentic person (vignette 6). In so doing, she also evaluates her own and her cousin's behavior as socially appropriate and inappropriate respectively. The narrative images in this example reinforce such evaluation by conveying the close bond between the two characters in the story.

\subsection{Pragmatic Choices, Identity, and Connection-Autonomy in Resolution Episodes}

Resolution episodes in learners' digital texts presented a solution to the problem introduced in conflict episodes. As opposed to conflict episodes, learners' pragmatic choices in the resolution of their stories were not affected by the type of social bond they selected as the topic of their narratives. They were the same across story types, and included the use of self-oriented supportive acts, positive qualifying adjectives within other-oriented supportive acts, indirect quotations, and narrative images mainly of an explicit kind (see Table 2).

\section{Table 2}

Pragmatic Choices in Resolution Episodes

Communicative acts:

- Supportive (self- and other-oriented)

Upgraders and downgraders:

- Positive qualifying adjectives (other-oriented)

Quotations:

Indirect

Explicit narrative images 
Learners employed these resources to build competent identities for themselves and their relational partner and fluctuate between connection and autonomy. Such relational work involved a process of identity transformation in this person, who became a more positive persona in stories about an underachieving kid and returned to his/her "old" self in family and school narratives. These identity processes emphasized the notion of identity as a site of struggle and were triggered by the learner's help whose identity was also positively transformed as a result.

Learners used the resources in Table 2 to frame their help as a type of instruction and learning, which enabled them to re-shape connection-autonomy as "superiority-equality", and craft their selves as experts, teachers, and learners, whilst rendering the other person as an apprentice and a competent agent. In building such identities for themselves, learners levelled the power difference underlying these positions through the attribution of a learner identity to both. The discursive construction of these identities went beyond the traditional "teacher-student" dichotomy, as pointed out in previous identity research (e.g., Darvin \& Norton, 2015; Thorne et al., 2015). Figure 3 exemplifies these findings.

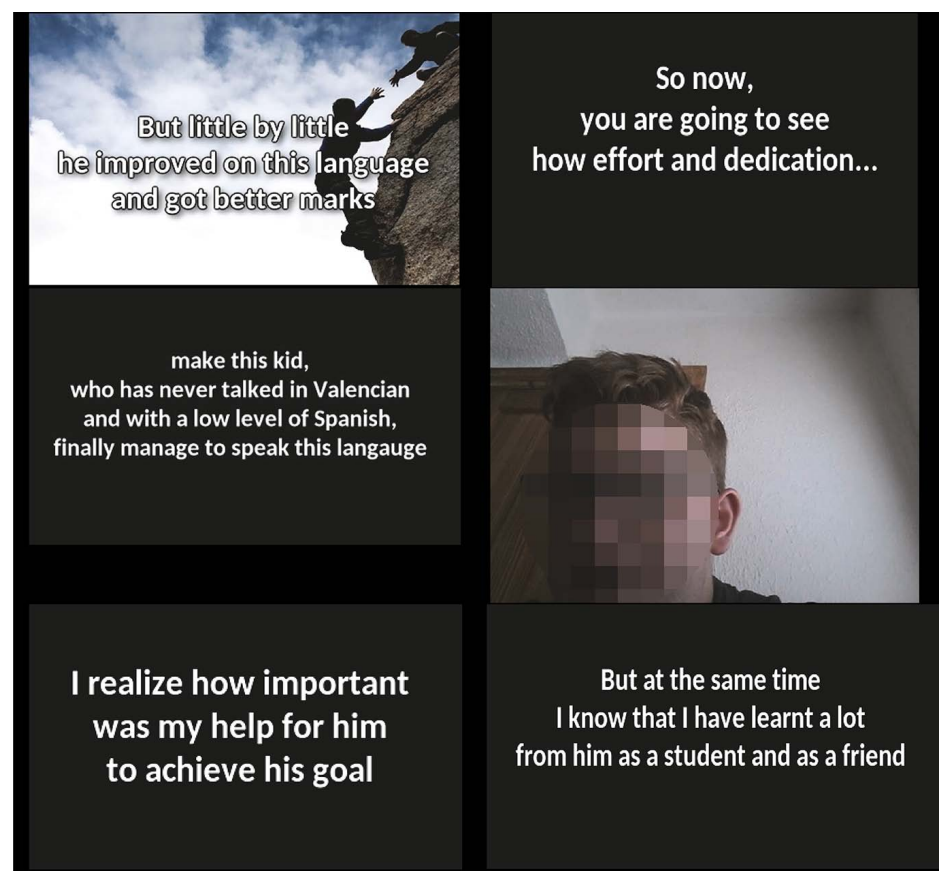

Figure 3. Example from Participant 11's story.

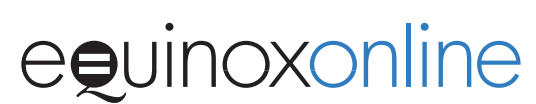


This example is part of the digital story of Participant 11, a male learner who narrates his relationship with a boy who had trouble learning Valencian. It illustrates the second half of the resolution episode of his story, in which the learner describes how he helped this boy by teaching him the language, and how the kid improved with his help. In his narration, Participant 11 ascribes the boy an identity of competent individual by means of an otheroriented supportive act (vignette 1), which includes a positive qualifying adjective ("better"). The learner also resorts to other-oriented supportive acts in vignettes 2 and 3 for such positive identity construction, which is reinforced in vignette 4 through a video that illustrates how the boy could finally speak Valencian. The learner describes this boy's positive identity as the result of a process of identity transformation that involved the learner's help, as shown by the implicit narrative image in vignette 1 , and the boy's "effort" and "dedication" (vignette 2). This way, he depicts the boy's identity as a site of struggle both visually (vignette 1 ) and verbally (vignette 2 ).

The learner makes his help explicit in vignette 5, and implicitly builds for himself identities of teacher and expert through a self-oriented supportive act that takes the form of self-reflection. Such reflection continues in vignette 6 , in which he also utters a self-oriented supportive act, whereby he acknowledges the kid's positive effect in his persona, whilst attributing himself an identity of "student" and a "friend". The learner thus levels the power difference in his relationship with the child and empowers himself and the latter as a result. By claiming an identity of "student" and a "friend", he also re-shapes his relationship with the child as one of "superiority-equality", emphasizing the equality pole of the dialectic. In so doing, he also points out their mutual convergence towards connection in their relationship.

\section{Conclusions}

This study has attempted to address the under-researched link between L2 pragmatics and identity in digital spaces by exploring L1 Spanish learners' pragmatic choices for identity construction in their enactments of connection-autonomy in digital stories. These choices were observed to range from students' selection of the topic of their stories according to types of social bonds to their use of certain semiotic resources in these texts. Learners' focus on their relationship with an underachieving child, a family relative, or a school friend influenced the resources they used for identity construction and the enactment of connection-autonomy in the conflict episodes of their stories.

However, topic choice in terms of these relationships did not affect learners' use of semiotic resources for meaning making in the resolution episodes of these texts.

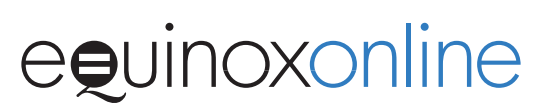


Therefore, in the conflict episodes of stories about the learner's relation with an underachieving child, learners resorted to self- and other-oriented supportive acts, and positive evaluative adjectives within the latter to build positive identities for themselves and the child, which clashed with negative identities ascribed to him/her by other social agents. Learners also used these resources to simultaneously enact connection with, and autonomy from, the child with an increasing tendency towards connection from both parties in the relationship. In the conflict episodes of school friends and family relatives, learners' pragmatic choices included self-oriented supportive acts like in the underachieving child stories, but also comprised negative qualifying adjectives in other-directed unsupportive acts targeted to their relational partner, as well as indirect and direct quotations. Learners employed these resources to build an identity of authentic and sensitive individual for themselves and the opposite identity for the other person. This identity clash paralleled a relational clash that was observed in the learner's move towards connection and their partner's pull towards autonomy. This triggered learners' evaluation of their own and the other party's behavior and revealed both parties' relational work and the discursive struggle emerging thereof.

In the resolution episodes of their digital stories, learners preferred selforiented supportive acts, positive qualifying adjectives within other-oriented supportive acts, and indirect quotation to (a) craft their selves as experts, teachers, and learners; (b) build an identity of competent agent for their relational partner; and (c) shape connection-autonomy as "superiority-equality". However, in both the conflict and resolution episodes of learners' digital stories, they mainly employed explicit narrative images to convey all these meanings.

In sum, the findings of this study underscore the value of digital stories for providing learners with an opportunity to craft their identities in the target language in ways that match who they are or desire to be. It is also hoped that they may have modestly contributed to elucidating the relationship between L2 pragmatics and identity construction in these digital products, and by extension, in digital spaces.

\section{Acknowledgments}

I am indebted to the anonymous reviewers of this article for their insightful comments and suggestions on an earlier version of this paper.

\section{About the Author}

María Dolores García-Pastor is a Professor in the Department of English Language and Literature Teaching at the University of Valencia, Spain. Her research interests are within English as a foreign language (EFL) teaching and learning,

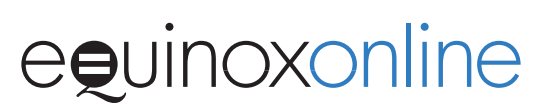


more specifically, identity, anxiety, and (im)politeness. Her publications include articles in language teaching and linguistic journals (European Journal of Special Needs Education, Digital Education Review, Signos, etc.), and book chapters by national and international publishers (Mouton de Gruyter, Peter Lang, etc.). She has a PhD and MA in English linguistics (University of Valencia), and an MA in Communication Studies (University of Iowa, USA).

\section{References}

Alcón Soler, E., \& Martínez-Flor, A. (2008). Pragmatics in foreign language contexts. In E. Alcón Soler \& A. Martínez-Flor (Eds.), Investigating pragmatics in foreign language learning, teaching and testing (pp. 3-21). Clevedon, England: Multilingual Matters. https://doi.org/10.21832/9781847690869

Baxter, L. A. (1993). The social side of personal relationships: A dialectical perspective. In S. Duck (Ed.), Social context and relationships (pp. 139-156). London, England: Sage.

Baxter, L. A., \& Montgomery, B. M. (1996). Relating, dialogues and dialectics. New York, NY: The Guilford Press.

Beebe, L. M., \& Takahashi, T. (1989). Sociolinguistic variation in face-threatening speech acts: Chastisement and disagreement. In M. R. Eisenstein (Ed.), The dynamic interlanguage: Empirical studies in second language variation (pp. 199-218). New York. NY: Springer. https://doi.org/10.1007/978-1-4899-0900-8_13

Beebe, L., \& Waring, H. Z. (2005). Pragmatic development in responding to rudeness. In J. Frodesen \& C. Holten (Eds.), The power of context in language teaching and learning: Festschrift in honor of Marianne Celce-Murcia (pp. 67-79). Boston, MA: Heinle \& Heinle.

Black, R. W. (2009). Online fan fiction, global identities, and imagination. Research in the Teaching of English, 43, 397-425.

Blum-Kulka, S. (1990). You don't touch lettuce with your fingers: Parental politeness in family discourse. Journal of Pragmatics, 14, 259-288. https://doi.org/10.1016/0378-2166 (90)90083-P

Chen, H-I. (2013). Identity practices of multilingual writers in social networking spaces. Language Learning \& Technology, 17(2), 143-170. https://doi.org/10125/44328

Darvin, R., \& Norton, B. (2015). Identity and a model of investment in applied linguistics. Annual Review of Applied Linguistics, 35, 36-56. https://doi.org/10.1017/S0267190514 000191

Davis, J. M. (2007). Resistance to L2 pragmatics in the Australian ESL context. Language Learning, 57, 611-649. https://doi.org/10.1111/j.1467-9922.2007.00430.x

Félix-Brasdefer, J. C. (2004). Interlanguage refusals: Linguistic politeness and length of residence in the target community. Language Learning, 54, 587-653. https://doi.org/10 $.1111 / \mathrm{j} .1467-9922.2004 .00281 . \mathrm{x}$

Fong, C. J., Lin, S., and Engle, R. A. (2016). Positioning identity in computer-mediated discourse among ESOL learners. Language Learning \& Technology, 20(3), 142-158. https://doi.org/10125/44486

García-Pastor, M. D. (2012). EFL teaching with a view to the classroom. In M. D. GarcíaPastor (Ed.), Teaching English as a foreign language: Proposals for the language classroom (pp. 12-26). Valencia, Spain: Perifèric.

García-Pastor, M. D. (2017). Learners' identities at stake: Digital identity texts in the EFL classroom. Language Value, 9, 36-61. https://doi.org/10.6035/LanguageV.2017.9.3 
García-Pastor, M. D. (2018a). Textos de identidad digitales: Una valiosa herramienta para el estudio de la construcción de la identidad y el aprendizaje lingüístico en ILE. Signos, 50, 24-44. https://doi.org/10.4067/S0718-09342018000100024

García-Pastor, M. D. (2018b). Learner identity in EFL: An analysis of digital texts of identity in higher education. Digital Education Review, 33, 55-76.

García-Pastor, M. D. (in press). Digital storytelling and learners' dialogical construction of identity in EFL. In F. Nami (Ed.), Digital storytelling in second and foreign language teaching. Bern, Switzerland: Peter Lang.

Gómez-Laich, M. P. (2016). Second language learners' divergence from target language pragmatic norms. Studies in Second Language Learning and Teaching, 6, 249-269. https://doi.org/10.14746/ssllt.2016.6.2.4

Gregori-Signes, C. (2008). Integrating the old and the new: Digital storytelling in the EFL language classroom. GRETA, 16, 43-49.

Hassall, T. (2013). Pragmatic development during short-term study abroad: The case of address terms in Indonesian. Journal of Pragmatics, 55, 1-17. https://doi.org/10.1016 j.pragma.2013.05.003

Ishihara, N. (2009). Transforming community norms: Potential of L2 speakers' pragmatic resistance. In M. Hood (Ed.), Proceedings of the 2008 Temple University of Japan colloquium on language learning (pp. 1-10). Tokyo, Japan.

Ishihara, N. \& Tarone, E. (2009). Subjectivity and pragmatic choice in L2 Japanese: Emulating and resisting pragmatic norms. In N. Taguchi (Ed.), Pragmatic competence: Mouton series in pragmatics 5 (pp. 101-128). Berlin, Germany: Mouton de Gruyter.

Iwasaki, N. (2011). Learning Japanese "politeness" and "impoliteness": Young American men's dilemmas during study abroad. Japanese Language and Literature, 45, 67-106.

Kasper, G. (1990). Linguistic politeness: Current research issues. Journal of Pragmatics, 14, 193-218. https://dx.doi.org/10.1016/0378-2166(90)90080-W

Kim, E. Y., \& Brown, L. (2014). Negotiating pragmatic competence in computer mediated communication: The case of Korean address terms. CALICO Journal, 31, 264-284. https://doi.org/10.11139/cj.31.3.264-284

Kim, H-Y. (2014). Learner investment, identity, and resistance to second language pragmatic norms. System 45, 92-102. https://dx.doi.org/10.1016/j.system.2014.05.002

Klimanova, L., \& Dembovskaya, S. (2013). L2 identity, discourse, and social networking in Russian. Language Learning \& Technology, 17(1), 69-88. https://dx.doi.org/10125 124510

Kress, G., \& van Leeuwen, T. (2006). Reading images: The grammar of visual design. London, England: Routledge. https://doi.org/10.4324/9780203619728

Lambert, J. (2010). Cookbook for digital storytelling. New York, NY: Digital Diner Press.

Leech, G. N. (1983). Principles of pragmatics. New York, NY: Longman.

LoCastro, V. (2001). Individual differences in second language acquisition: Attitudes, learner subjectivity, and L2 pragmatic norms. System, 29, 69-89. https://doi.org/10.1016 /S0346-251X(00)00046-4

Locher, M. A. (2008). Relational work, politeness and identity construction. In G. Antos, E. Ventola, \& T. Weber (Eds.), Handbooks of applied linguistics. volume 2: Interpersonal communication (pp. 509-540). Berlin, Germany: Mouton de Gruyter.

Locher, M. A., \& Watts, R. J. (2005). Politeness theory and relational work. Journal of Politeness Research, 1, 9-33. https://doi.org/10.1515/jplr.2005.1.1.9

Locher, M. A., \& Watts, R. J. (2008). Relational work and impoliteness: Negotiating norms of linguistic behavior. In D. Bousfield \& M. A. Locher (Eds.), Impoliteness in language:

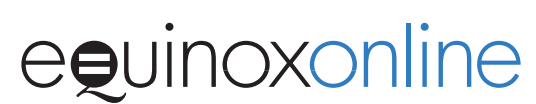


Studies on its interplay with power in theory and practice (pp. 77-99). Berlin, Germany: Mouton De Gruyter.

Norton, B. (1995). Social identity, investment and language learning. TESOL Quarterly, 29, 9-31. https://doi.org/10.2307/3587803

Norton, B. (2013). Identity and language learning: Extending the conversation (2nd ed.). Bristol, England: Multilingual Matters. https://doi.org/10.21832/9781783090563

Norton, B., \& De Costa, P. (2018). Research tasks on identity in language learning and teaching. Language Teaching, 51, 92-112. https://doi.org/10.1017/S0261444817000325

Norton, B., \& Toohey, K. (2011). Identity, language learning, and social change. Language Teaching, 44, 412-446. https://doi.org/10.1017/S0261444811000309

Oskoz, A., \& Elola, I. (2016). Digital stories: Bringing multimodal texts to the Spanish writing classroom. ReCALL, 28, 326-342. https://doi.org/10.1017/S0958344016000094

Renandya, W. (in press). Make a difference. In W. Renandya \& F. D. Floris (Eds.), Inspirational stories from English language classrooms. Jakarta, Indonesia: TEFLIN.

Robin, B. (2016). The power of digital storytelling to support teaching and learning. Digital Education Review, 30, 17-29.

Siegal, M. (1996). The role of learner subjectivity in second language sociolinguistic competency: Western women learning Japanese. Applied Linguistics, 17, 356-382. https:// doi.org/10.1093/applin/17.3.356

Tannen, D. (1993). What's in a frame? Surface evidence for underlying expectations. In D. Tannen (Ed.), Framing in discourse (pp. 14-56). Oxford, England: Oxford University Press.

Thomas, J. A. (1983). Cross-cultural pragmatic failure. Applied Linguistics, 4, 91-112. https:// doi.org/10.1093/applin/4.2.91

Thorne, S. L., \& Black, R. (2011). Identity and interaction in internet mediated contexts. In C. Higgins (Ed.), Identity formation in globalizing contexts: Language learning in the new millennium, vol. 1 (pp. 257-278). Berlin, Germany: Mouton de Gruyter. https://doi .org/10.1515/9783110267280.257

Thorne, S. L., Sauro, S, \& Smith, B. (2015). Technologies, identities, and expressive activity. Annual Review of Applied Linguistics, 35, 215-233. https://doi.org/10.1017/S026719 0514000257

Wildner-Bassett, M. E. (1994). Intercultural pragmatics and proficiency: "Polite" noises for cultural appropriateness. International Review of Applied Linguistics in Language Teaching (IRAL), 32, 3-18. https://doi.org/10.1515/iral.1994.32.1.3

Wortham, S. (2006). Learning identity: The joined local emergence of social identification and academic learning. Cambridge, England: Cambridge University Press.

Yi, Y. (2007). Engaging literacy: A biliterate students' composing practices beyond school. Journal of Second Language Writing, 16, 23-39. https://doi.org/10.1016/j.jslw.2007.03 .001 